\title{
European-scale analysis of seasonal variability in limpet grazing activity and microalgal abundance
}

\author{
S. R. Jenkins ${ }^{1, *}$, F. Arenas ${ }^{2}$, J. Arrontes ${ }^{2}$, J. Bussell ${ }^{1}$, J. Castro ${ }^{3}$, R. A. Coleman ${ }^{4}$, \\ S. J. Hawkins ${ }^{4}$, S. Kay ${ }^{1}$, B. Martínez ${ }^{2}$, J. Oliveros ${ }^{2}$, M. F. Roberts ${ }^{4}$, S. Sousa ${ }^{3}$, \\ R. C. Thompson ${ }^{4}$, R. G. Hartnoll ${ }^{1}$ \\ ${ }^{1}$ Port Erin Marine Laboratory (University of Liverpool), Port Erin, Isle of Man IM9 6JA, British Isles \\ ${ }^{2}$ Departamento de Biologia de Organismos y Sistemas, Universidad de Oviedo, 33071 Oviedo, Spain \\ ${ }^{3}$ Laboratorio de Ciencias do Mar, Universidade de Evora, Avenida Vasco da Gama, Apartade 190, 7520-903 Sines, Portugal \\ ${ }^{4}$ Division of Biodiversity and Ecology, School of Biological Sciences, University of Southampton, Bassett Crescent East, \\ Southampton SO16 7PX, United Kingdom
}

\begin{abstract}
The film of microalgae and macroalgal propagules which coats intertidal rocks is the main food resource of limpets, the dominant grazers on exposed shores of north-west Europe. Spatial and temporal variability in feeding activity of limpets and abundance of microalgae were examined at mid-tide level across a European gradient from the Isle of Man in the British Isles to south-west Portugal. Feeding activity was assessed as the frequency of radula scrapes on wax surfaces placed on the shore. This was undertaken monthly at 2 shores at each of 4 locations, the Isle of Man, south-west England, northern Spain and south-west Portugal, over 1 yr. The abundance of the microalgal film was determined simultaneously at 3 of the 4 locations by measuring the concentration of chlorophyll $a$ on the rock surface. The density and species diversity of limpets increased with decreasing latitude. This was mirrored by a trend of increased levels of limpet grazing, although 1 location (northern Spain) did not fit this trend. Seasonal changes in limpet grazing intensity were found at 3 of the 4 locations, characterised by elevated grazing during the summer and autumn. The seasonal variations resulted from changes in the level of foraging of individual limpets and were positively correlated with mean sea temperature in the Isle of Man and south-west England. The pattern of grazing activity was not solely a function of sea temperature. In the Isle of Man, grazing by Patella vulgata declined during the later stages of gonad development and increased following spawning. Seasonal variation in the standing stock of microalgae, measured as the concentration of chlorophyll $a$, was found at all 3 locations examined, the Isle of Man, south-west England and northern Spain, with greater abundance in the winter compared to summer. This pattern was consistent over both large (among locations: 100s of kilometres) and medium (between shores: 1000s of metres) scales. There were no correlations between microalgal abundance and limpet grazing activity at any location. There were significant negative correlations between chlorophyll $a$ and maximum monthly air temperature and monthly sunshine hours. Comparison of microalgal abundance among locations showed a general decline in standing stock with decreasing latitude, but differences between specific locations varied with season. South-west England showed similar levels of microalgal abundance to the most northerly location (Isle of Man) in winter, and to the most southerly location (northern Spain) in the summer.
\end{abstract}

KEY WORDS: Biofilm $\cdot$ Herbivory $\cdot$ Large scale $\cdot$ Limpets $\cdot$ Spatial variation $\cdot$ Temporal variation Resale or republication not permitted without written consent of the publisher

\section{INTRODUCTION}

Biofilms form on any hard surface immersed in water, and are an important component of the benthos in marine (e.g. Underwood 1984a, Wahl 1989, Hill \&

ㅇ Inter-Research 2001
Hawkins 1991) and freshwater (e.g. Lock 1993) environments. Such films are 3-dimensional structures made up of bacteria, diatoms, cyanobacteria and protozoa embedded in a muco-polysaccharide matrix (Wahl 1989, Hill \& Hawkins 1991, Nagarkar \& Williams

*E-mail: stu@liverpool.ac.uk 
1997). The microbial film which coats intertidal rock surfaces may make an important contribution to primary production in this habitat and provides a food resource for microphagous grazers such as limpets. In addition, the film provides the site of first attachment and early growth of settling macroalgae and sessile invertebrates. Despite the importance of this biofilm in community dynamics of rocky shores (see Raffaelli \& Hawkins 1996 for review) it has received relatively little attention, mainly because of technical difficulties in sampling and quantification (MacLulich 1986, Hill \& Hawkins 1990, Nagarkar \& Williams 1997). Difficulties in the identification of the components of epilithic microbial communities have limited detailed taxonomic studies in intertidal habitats (but see Potts 1980, Whitton \& Potts 1982, Nagarkar \& Williams 1999).

Description of spatial patterns in epilithic microalgal films has been limited mainly to studies over the vertical gradient of the shore (e.g. Aleem 1950, Castenholz 1963, Underwood 1984a, MacLulich 1987) and effects of microhabitat variation (Hill \& Hawkins 1991, Williams 1994). Seasonal variation has been more extensively studied. High levels of microalgal abundance in late autumn and winter relative to summer have been recorded at a range of locations world-wide, in Australia (Underwood 1984a, MacLulich 1987), Japan (Fuji et al. 1991), Britain (Aleem 1950, Hill \& Hawkins 1991) and North America (Nicotri 1977).

In the north-east Atlantic, the dominant grazers on exposed rocky shores are patellid limpets (Lewis 1964). Patella spp. are microphagous grazers and consumption of the epilithic microbial film with associated algal propagules regulates the level of macroalgal recruitment (see Hawkins et al. 1992 for review). The role of limpets in structuring macroalgal communities is well known, but the relationship between limpets and their food supply, epilithic microalgae, has received less attention (but see Branch \& Branch 1980, Creese \& Underwood 1982, Underwood 1984b). Seasonal and spatial variation in food resources could clearly have important implications for population dynamics and life history strategies of microphagous gastropods (Bosman \& Hockey 1988). Also, grazers may have an important role in mediating spatial and temporal variation in the microbial film (Thompson 1996).

Concurrent sampling of microalgal abundance and grazing effort of dominant microphagous grazers has been undertaken previously in the Isle of Man (Thompson 1996). A clear seasonal cycle of foraging effort in the limpet Patella vulgata and microalgal abundance was demonstrated, although no relationship between the 2 variables was apparent. Patellid limpets are abundant on exposed rocky shores along the Atlantic coast of Europe. We aimed to determine whether the seasonal patterns of microalgal abun- dance and limpet foraging effort recorded on the Isle of Man are general on a European scale. In addition, this study enabled determination of how microalgal standing stock and the level of grazing intensity on exposed rocky shores changes over a latitudinal gradient.

Measurement of microalgal abundance on hard substrata may be undertaken in a variety of ways. Direct observation of the film using light or fluorescent microscopy (e.g. Castenholz 1963, Nicotri 1977, Underwood 1984a, MacLulich 1986), scanning electron microscopy (e.g. MacLulich 1986, 1987, Hill \& Hawkins 1990) and, more recently, confocal microscopy (Norton et al. 1998) has been used with some success. However, such techniques are time-consuming and inappropriate for the quantification of microalgae in large numbers of samples. Chlorophyll has been used by a number of workers as an indirect estimate of microalgal abundance in epilithic films (e.g. Castenholz 1963, Nicotri 1977, Underwood 1984a, MacLulich 1986, 1987). Such an approach has been justified by demonstration of correlations between chlorophyll concentration and algal cell abundance in intertidal habitats at a range of locations (Underwood 1984a, Fuji et al. 1991, Hill \& Hawkins 1991). Analysis of chlorophyll a ( $\mathrm{chl}$ a) was undertaken in our study using the 'standard' method proposed by Thompson et al. (1999) for epilithic microalgae.

An additional aim of this study was to examine the relationship between the breeding cycle and grazing effort in Patella vulgata. Orton et al. (1956) speculated that gonad development in $P$. vulgata during autumn resulted in a decline in feeding activity and reduction in gut volume owing to the limited internal space available following increased gonad size. A decline in feeding activity in late summer has been confirmed (Thompson 1996), and here we tested the hypothesis that spawning in $P$. vulgata is followed by a rapid increase in feeding activity.

\section{MATERIAL AND METHODS}

Study sites. Sampling was undertaken at 4 European locations, the Isle of Man, south-west England, northern Spain and south-west Portugal, covering approximately $1600 \mathrm{~km}$ of latitude (Fig. 1). All locations were in fully saline environments with maximum tidal ranges of $6.0 \mathrm{~m}$ (Isle of Man), $4.5 \mathrm{~m}$ (south-west England), $4.3 \mathrm{~m}$ (northern Spain) and $3.7 \mathrm{~m}$ (south-west Portugal). At each location, 2 exposed rocky shores were selected. Across this latitudinal gradient, such shores are dominated at mid-tide level by barnacles and patellid limpets, with a variable but generally lowmoderate cover of fucoid algae. For descriptions of shores see references listed in Fig. 1. 


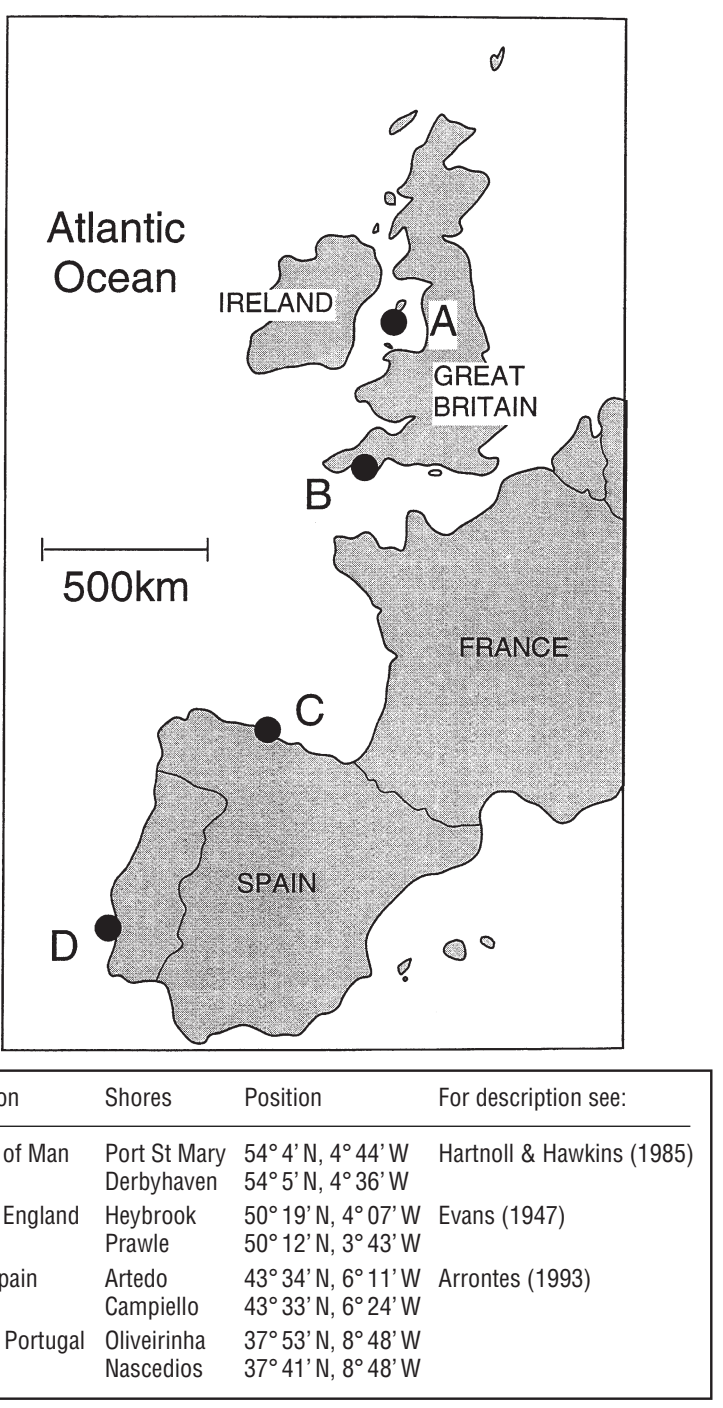

Fig. 1. Map showing positions of the 4 sampling locations in north-west Europe. A: Isle of Man; B: south-west England; C: northern Spain; D: south-west Portugal

Limpet grazing activity. Grazing activity was assessed using the method developed by Thompson et al. (1997), which relies on the distinctive marks made by the feeding apparatus of marine molluscan herbivores. These grazing marks can be recorded on discs of wax placed into pre-formed holes in the rock surface and grazing activity quantified by assessing the area of wax surface scraped.

Validation of method: Further validation of this technique was carried out by assessing the response of Patella vulgata to wax discs using video analysis. A large marine pond at Port Erin Marine Laboratory with a semi-natural tidal cycle and a resident population of limpets was used. An underwater video camera connected to a time-lapse recorder was attached to a frame which was then bolted to the vertical wall of the pond. The system was equipped with underwater lights covered with a red filter. The camera had a $0.7 \mathrm{~m}^{2}$ field of view of the wall, which encompassed the home-scar positions of 11 limpets. Fifteen wax disc holes were interspersed between the 11 limpets, which were within the field of view. To increase the number of limpet-wax disc encounters, a $30 \mathrm{~mm}$-high fence of plastic-coated wire mesh was fixed to enclose the 11 home scars within an area of $0.42 \mathrm{~m}^{2}$. The resulting density of 26 limpets $\mathrm{m}^{-2}$ was typical of limpet populations at this location. Wax discs were deployed for 2 separate periods of $7 \mathrm{~d}$ separated by a period of $4 \mathrm{~d}$; each of these periods was filmed continuously.

Video records were analysed to evaluate the response of foraging limpets to encounters with wax discs and to determine whether the type of response changed over time. Responses were scored as (1) rejection: on encountering a wax disc limpets changed direction so as to avoid disc; (2) no response; (3) decreased speed of travel over disc; (4) increased speed of travel over disc. These responses were compared to activity for 15 randomly selected 'control discs' which were allocated positions and marked on acetate covering the video monitor. Responses when limpets encountered these control positions were scored in the same way.

Seasonal variation: Seasonal variation in grazing activity of limpets was investigated on the 2 selected shores at all 4 European locations. On each shore, 6 sites, all at least $10 \mathrm{~m}$ apart, were chosen at mid-shore level on gently sloping substrata. At each site, an array of 9 holes was drilled within an area of $2 \mathrm{~m}^{2}$. For details on the preparation of holes and of wax discs see Thompson et al. (1997). From April 1997 to July 1998 at approximately monthly intervals, wax discs were placed in the pre-formed holes and retrieved $14 \mathrm{~d}$ later. Discs were examined under a binocular microscope using an eyepiece graticule with 25 dots regularly spaced over a circular area. In Portugal, a graticule with 81 regularly spaced dots was used. Grazing marks of limpets were recognised from the descriptions of Thompson et al. (1997), and the area covered by such marks on each disc was estimated by using the graticule dots as 'point intercepts'. Use of the graticule provided an objective means of scoring discs; this was especially important when scoring was undertaken by different people. The average value of 9 discs in each array was calculated to give an estimate of grazing activity at each site. The density of limpets and the proportions of different species were assessed on both shores at each location at intervals over the period of study.

Relationship with reproductive cycle: The relationship between the reproductive cycle in Patella vulgata and temporal variation in grazing activity was investigated in the Isle of Man by continuing fieldwork beyond July 1998. The same sets of holes were utilised, 
and wax discs were deployed over consecutive 2 wk periods from August to the end of November 1998. Over the same period, 50 limpets in the size range 30 to $50 \mathrm{~mm}$ were collected approximately weekly from mid-tide level on each of the 2 shores, avoiding areas adjacent to wax disc sites. Limpets were dissected in the laboratory immediately after collection, and gonad development was assessed by the classification scheme of Orton et al. (1956). The mean gonad index was calculated for the limpet population of each shore.

Microalgal abundance. At 3 of the 4 locations used to investigate grazing activity (Isle of Man, south-west England and northern Spain) a simultaneous study was made of seasonal variation in abundance of the microalgal film. Chl a levels were used as an index of microalgal standing stock.

At each site (6 on each shore) used for estimating limpet grazing activity, 3 samples of rock, each with a surface area of at least $4 \mathrm{~cm}^{2}$, were removed at monthly intervals using a hammer and small chisel. Samples of rock were taken from areas of open substrate devoid of macroalgae or sessile invertebrates and as close to the arrays of wax discs as possible. To limit the confounding effect of surface rugosity on estimates of $\operatorname{chl} a_{\text {, only }}$ smooth areas of rock were selected. The amount of chl a in each sample was estimated as follows: samples were initially washed and hydrated in filtered sea water. Extraction was made using cold methanol over a period of between 5 and $24 \mathrm{~h}$ and absorbance of the resulting solution was determined at 665 and $750 \mathrm{~nm}$. The surface area of each rock sample was determined by image analysis, and the level of chl a per unit area of rock surface was calculated. For full details of methodology see Thompson et al. (1999).

A comparison between chl a estimates obtained by different laboratories was made in order to confirm that any differences between locations were the result of geographic variability in the microbial film and not in the analytical technique. In May 1998, 9 rock chips were taken from each of 6 sites at an exposed shore on the south coast of England. For each site the chips were divided randomly into 3 groups and a total of 18 chips was sent to each laboratory. Samples were packed in ice and analysed within $5 \mathrm{~d}$ of collection.

Physical variables. Air and sea temperatures, experienced by organisms on both shores at all 4 locations, were recorded using Hugrun ${ }^{\mathrm{TM}}$ mini temperature recorders. These were programmed to record temperature every $30 \mathrm{~min}$, and were attached to exposed gently sloping rock substrata at mid-tide level in areas free from algae. Temperatures were thus recorded in full sunlight, approximately $5 \mathrm{~mm}$ above the substratum. The temperature recorders were removed from the shore at intervals and the data downloaded. Published tidal curves were used to determine periods of immersion and emersion, allowing air and sea temperature data to be extracted.

Data analysis. Data were analysed using ANOVA, and multiple comparisons of levels within significant factors were made using Student-Newman-Keuls (SNK) tests. Cochran's test (Winer 1971) was used to test for heterogeneity of variance.

\section{RESULTS}

\section{Limpet grazing activity}

Validation of method

There were 168 encounters between foraging limpets and wax discs. In $10 \%$ of these encounters limpets made a significant change of foraging direction (Response Type 1) (Fig. 2). Of the 117 encounters with control areas none produced this response. Response Types 3 (slow down) and 4 (speed up) were rare when encountering wax discs, making up $<5 \%$ of encounters, and even rarer in the controls. In $>80 \%$ of cases, limpets crossing wax discs showed no change in behaviour. The 11 limpets under scrutiny were exposed to wax discs for two $7 \mathrm{~d}$ periods, separated by a $4 \mathrm{~d}$ gap. The percentage of encounters per day which resulted in a rejection response showed no trend with time $(\mathrm{r}=$ 0.066, $\mathrm{n}=14, \mathrm{p}>0.8$; Fig. 3). Thus, in the short term, limpet reactions did not change with experience.

\section{Seasonal variation}

The density and species composition of limpets at mid-shore level varied greatly between locations (Table 1). Both species richness and total species den-

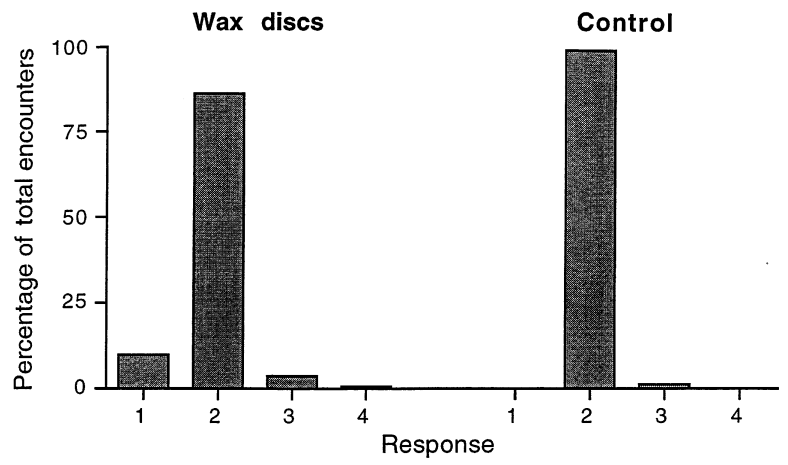

Fig. 2. Responses of grazing limpets to encounters with wax discs and control areas of rock, expressed as percentages of the total encounters with each substrate type over two $7 \mathrm{~d}$ periods (wax disc $\mathrm{n}=168$; control $\mathrm{n}=117$ ). Response Type $1=$ rejection-limpet changes direction; $2=$ no response; $3=\mathrm{de}-$ creased speed of travel over disc; $4=$ increased speed of travel over disc 


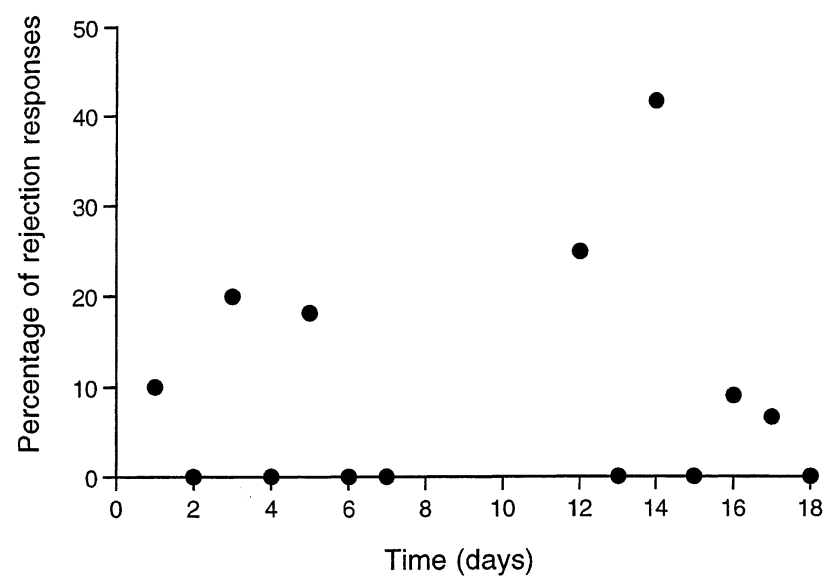

Fig. 3. Percentage of encounters classed as Type 1 (rejection) between grazing limpets and wax discs for each day over an $18 \mathrm{~d}$ period (two $7 \mathrm{~d}$ periods of video footage separated by $4 \mathrm{~d}$ )

sity increased from north to south. None of the locations showed seasonal trends in limpet density, although temporal variability was evident (Fig. 4). For example, in northern Spain the limited data set indicated a lower abundance during autumn on 1 shore. However, no relationship between the pattern of grazing revealed by wax discs (see below) and limpet density was evident at any location.

Seasonal variation in the area of wax disc scraped is summarised in Fig. 5. In the Isle of Man and south-west England, there were distinct seasonal changes in the level of limpet grazing which were consistent between the 2 shores at each location (Fig. 5). These 2 northerly locations showed a similar seasonal pattern, with lowest levels in late winter (January/February). Grazing intensity was higher during the rest of the year, with peaks in the early summer (only in 1998 in the Isle of Man) and late autumn. In south-west Portugal, the seasonal pattern of grazing was less clear but showed

Table 1. Density $\left(\mathrm{m}^{-2}\right)$ of limpet species found at mid-shore level on the 2 exposed shores at each location

\begin{tabular}{|llrc|}
\hline Location & Species & Shore 1 & Shore 2 \\
\hline Isle of Man & Patella vulgata & 27.1 & 30.8 \\
SW England & Patella vulgata & 82.2 & 115.4 \\
& Patella depressa & 43.8 & 40.2 \\
N Spain & Patella vulgata & 47.2 & 34.8 \\
& Patella depressa & 200.8 & 149.2 \\
SW Portugal & Patella vulgata & 0.8 & 2.0 \\
& Patella depressa & 200.4 & 228.4 \\
& Patella aspera & 2.8 & 1.6 \\
& Patella rustica & 0.3 & 0 \\
& Siphonaria pectinata & 47.2 & 21.2 \\
\hline
\end{tabular}
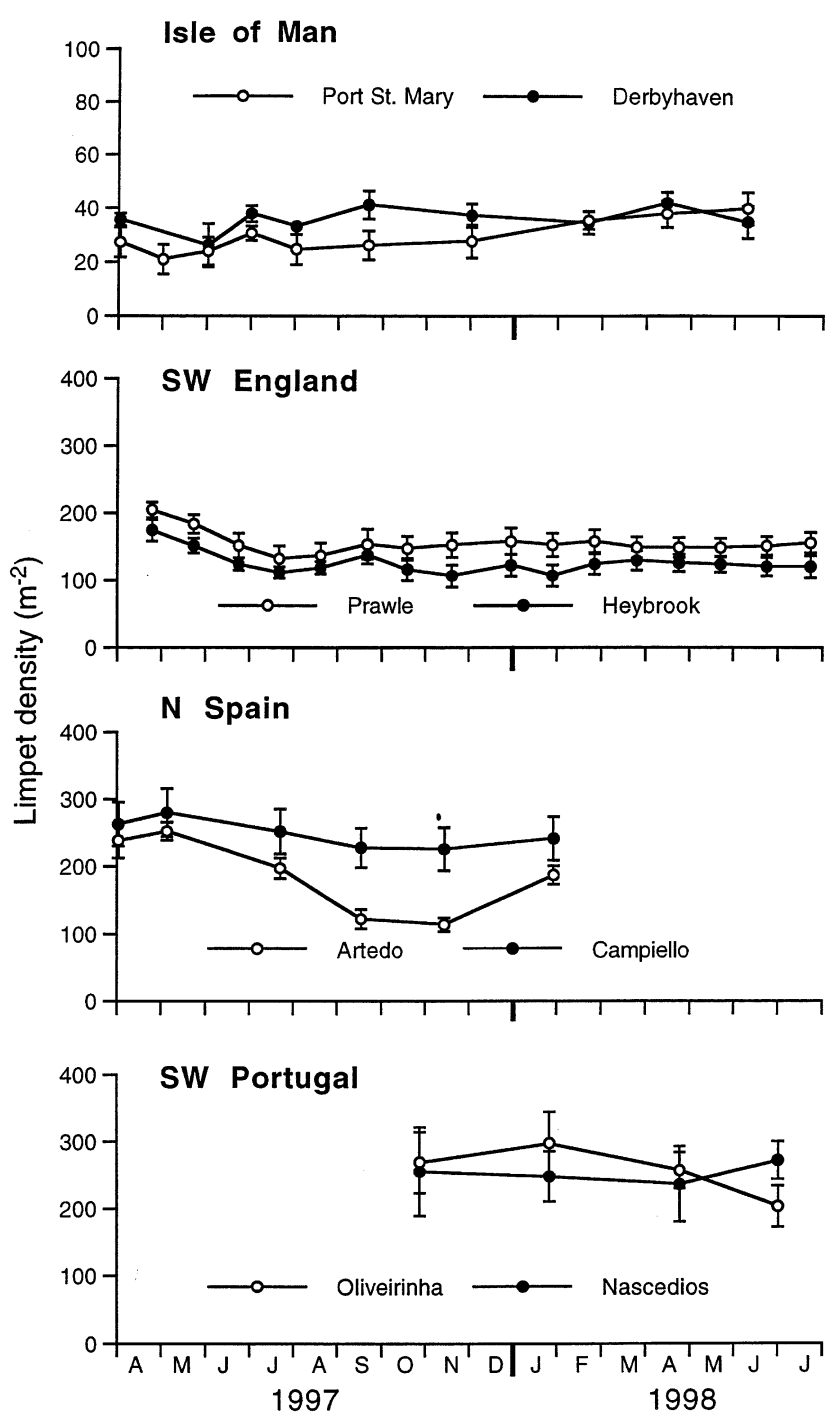

Fig. 4. Mean density of limpets per $\mathrm{m}^{2}$ at mid-tide level throughout the period of study on the 2 shores at each location. Note different scale for Isle of Man. Error bars $= \pm 1 \mathrm{SE}$

similarities to that in Britain, with a gradual increase through the summer to a peak in late autumn, followed by a gradual decline into early spring. In northern Spain, changes in grazing activity occurred, but there was no consistent pattern between the 2 shores.

Examination of the relationship between grazing activity and monthly mean sea temperature in the intertidal zone showed a significant correlation (1tailed test) in south-west England ( $\mathrm{r}=0.72, \mathrm{n}=16, \mathrm{p}<$ $0.01)$, the Isle of Man $(r=0.512, n=14, p<0.05)$ but not northern Spain $(\mathrm{r}=-0.41, \mathrm{n}=16, \mathrm{p}>0.05)$. In southwest Portugal, insufficient temperature data were collected to allow analysis.

The level of grazing, averaged over a 12 mo period (May 1997 to April 1998), showed distinct differences be- 
Table 2. ANOVA of mean level of limpet grazing activity over period May 1997 to April 1998 between 4 European locations. Cochran's test: $C=0.317, \mathrm{p}>0.05$. Sh: shore; Lo: location; Res: residual

\begin{tabular}{|c|c|c|c|c|c|c|}
\hline Source & df & MS & $F$ & $\mathrm{p}$ & & $F$ ratio vs \\
\hline Location & 3 & 2.98 & 20.03 & $<0.01$ & & Sh (Lo) \\
\hline Shore (Location) & 4 & 0.15 & 4.33 & $<0.01$ & & Res \\
\hline Residual & 40 & 0.03 & & & & \\
\hline \multicolumn{7}{|l|}{ SNK tests } \\
\hline \multicolumn{3}{|c|}{ Location $\mathrm{SE}=0.1114$} & \multicolumn{4}{|c|}{ Shore (Location) $\mathrm{SE}=0.0757$} \\
\hline \multirow{4}{*}{\multicolumn{3}{|c|}{ SW Portugal $>$ SW England > Isle of Man = N Spain }} & Isle of Man & & \multicolumn{2}{|l|}{ Shore $1=$ Shore 2} \\
\hline & & & SW England & \multicolumn{3}{|c|}{ Shore $1=$ Shore 2} \\
\hline & & & N Spain & \multirow{2}{*}{\multicolumn{3}{|c|}{ Shore $1<$ Shore 2}} \\
\hline & & & SW Portugal & & & \\
\hline
\end{tabular}

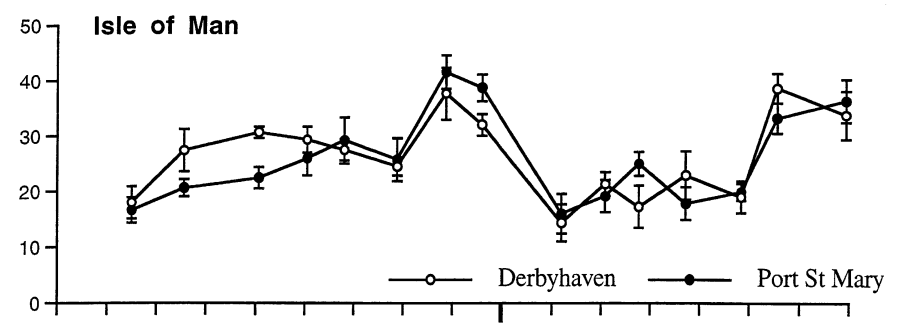

SW England
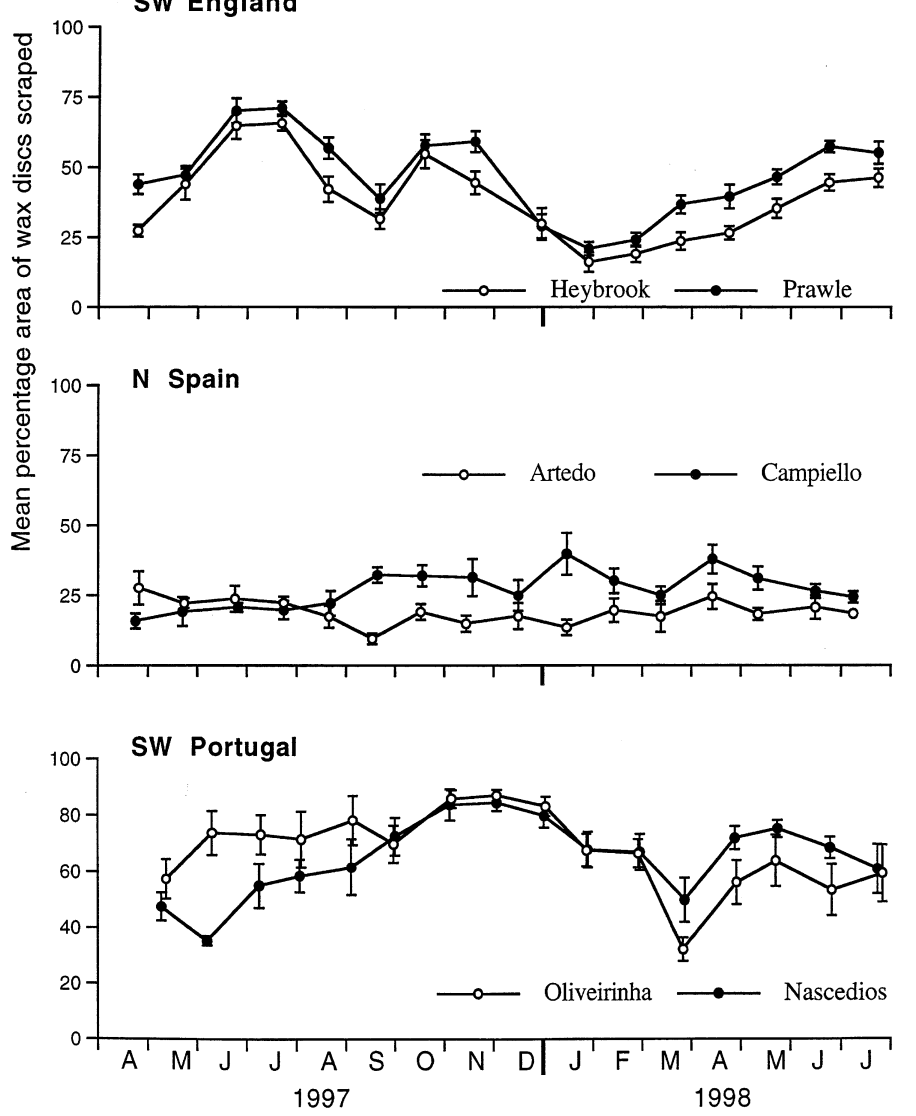

Fig. 5. Variation in grazing activity of limpets on the 2 shores at each location over 15 mo. Each point represents the estimate of grazing activity over a $2 \mathrm{wk}$ period and is the mean of 6 sites. Note different scale for Isle of Man. Error bars \pm 1 SE tween locations (Table 2). Levels were significantly higher in south-west Portugal than any other location (mean $66 \%$ ), and in south-west England grazing activity (mean $42 \%$ ) was significantly higher than in both the Isle of Man (mean 26\%) and northern Spain (mean $23 \%$ ). Significant differences between shores within each location occurred only in northern Spain (Table 2).

\section{Relationship with reproductive cycle}

The potential link between grazing activity and development of the gonad in Patella vulgata was examined on the Isle of Man in the autumn and early winter of 1998. The mean gonad index increased steadily through August and September and peaked in early October (Fig. 6). A dramatic decline occurred at the end of that month on both shores investigated, indicating the time of peak spawning. The grazing activity over this period differed between the 2 shores (Fig. 6). At Port St Mary, grazing levels were roughly constant until the middle of October. The $2 \mathrm{wk}$ period at the end of this month saw grazing activity increase from 29 to $43 \%$, coinciding with the decline in mean gonad index. At Derbyhaven there was no corresponding rapid increase in grazing activity, although the decline in mean gonad index did coincide with the start of a gradual increase.

\section{Microalgal abundance}

As a calibration exercise, the chl a content of replicate samples from the English south coast was determined by the laboratories on the Isle of Man, in southwest England and northern Spain. The 3 rock chips from each of 6 sites were treated as sub-samples and used to calculate a mean value from each site. Oneway ANOVA revealed no difference in the estimates of chl a concentration between the 3 laboratories $\left(\mathrm{df}_{2,15}\right.$; $F=1.317 ; \mathrm{p}>0.25$; Fig. 7). 


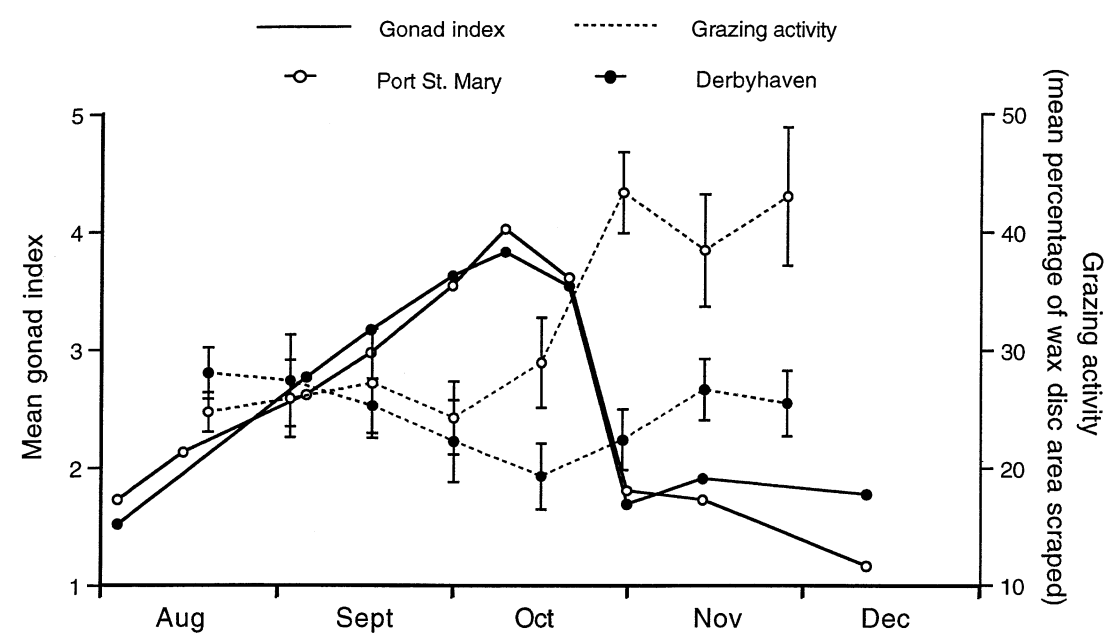

Fig. 6. Patella vulgata at 2 shores. Level of gonad development and grazing activity in mid-shore populations on the Isle of Man. Mean gonad index was calculated for individuals with shell length of 30 to $50 \mathrm{~mm}$. Each estimate of grazing activity is plotted at the end of the 2 wk period to which it applies. Error bars $= \pm 1 \mathrm{SE}$

In addition to this formal comparison, the shape of the curves generated by approximate monthly sampling is of interest. South-west England showed a much longer summer minimum than the Isle of Man. Chl a levels remained low and approximately constant from April to September 1997. In addition, the switch from summer minimum to autumn/winter maximum was faster in south-west England. On 1 shore (Heybrook) there was a 3-fold increase in mean chl $a$ within a month. On the Isle of Man changes were slower and more continuous, and in northern Spain even more so.

The relationship between microalgal abundance and the physical environment was examined by carrying out correlations between monthly levels of chl $a$ and maximum air tem-

The amount of chl a per unit area of rock surface showed a clear seasonal pattern in the Isle of Man and south-west England (Fig. 8) - levels were generally high in winter and low in summer. The pattern in northern Spain was less clear. Data from previous studies at midtide level on 1 shore in the Isle of Man (Hill \& Hawkins 1991, Thompson 1996) identified a summer period (June to August) as characterised by low chlorophyll levels, and a winter period (December to February) characterised by high levels. Chlorophyll data from 3 sample times during each of these a priori selected periods allows a formal comparison of chl a levels between seasons using ANOVA (see Morrisey et al. 1992). A mixed-model nested design was used with 4 factors: location (fixed), shore nested within location (random), season (fixed) and date nested within season (random) (Table 3). Post-hoc pooling was utilised to remove non-significant terms $(p>$ 0.25 ) to increase power and provide tests for certain factors (Underwood 1997). There was a significant interaction between both location and season and location and date, indicating that the effect of location varied with time. SNK tests of the interaction between location and season (Table 3, Fig. 9) show that at all 3 locations chl a concentration was greater in the winter than the summer. Comparison between locations in the summer showed significantly greater chl a concentration in the most northerly location, the Isle of Man, compared to south-west England and northern Spain (Fig. 9). In the winter, both the Isle of Man and south-west England showed higher levels than northern Spain. Thus, there was a switch in the groupings of locations between summer and winter: south-west England was grouped with the northerly location, the Isle of Man, in winter, but with the southerly location, northern Spain, in the summer. perature, mean sea temperature and mean sunshine hours. Chl a levels displayed significant negative correlations with the monthly maximum air temperature at all 3 locations, with mean number of sunshine hours only in south-west England and with mean sea temperature in the Isle of Man and northern Spain (Table 4). There was no significant relationship between chl a levels and limpet grazing activity at any location (Table 4).

\section{DISCUSSION}

\section{Grazing intensity}

The method used to evaluate limpet grazing activity allows investigation over much larger spatial and

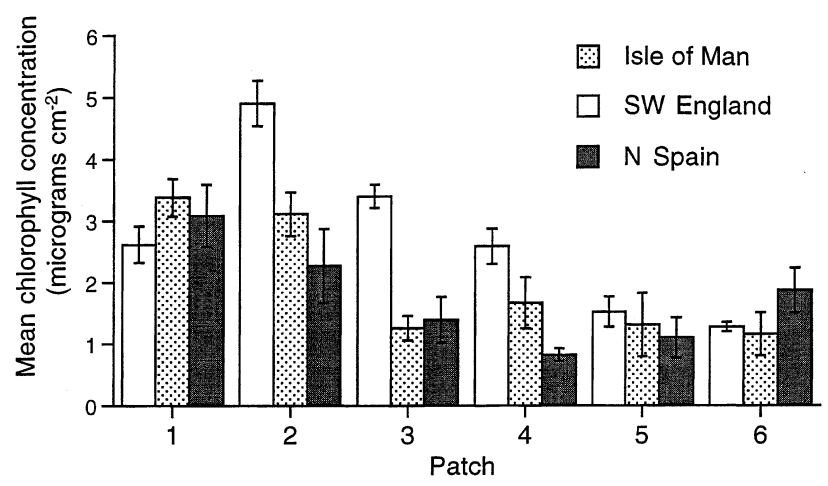

Fig. 7. Mean chlorophyll a concentrations on rock chips taken from 6 patches on an exposed shore on the south coast of England and analysed at laboratories in the Isle of Man, southwest England and northern Spain. Error bars $= \pm 1 \mathrm{SE}$ 
Table 3. ANOVA of chlorophyll a levels at 4 European locations in summer and winter. Cochran's test: $C=0.1187$, p $>0.05$. Da: date; Se: season; Sh: shore; Lo: location; Res: residual. Both Se $\times$ Sh (Lo) and Da (Se) $\times$ Sh $($ Lo) were non-significant $(p>0.25)$ and were thus pooled with the residual to increase the power of the test for Lo $\times$ Da (Se) and provide a test for Lo $\times$ Se

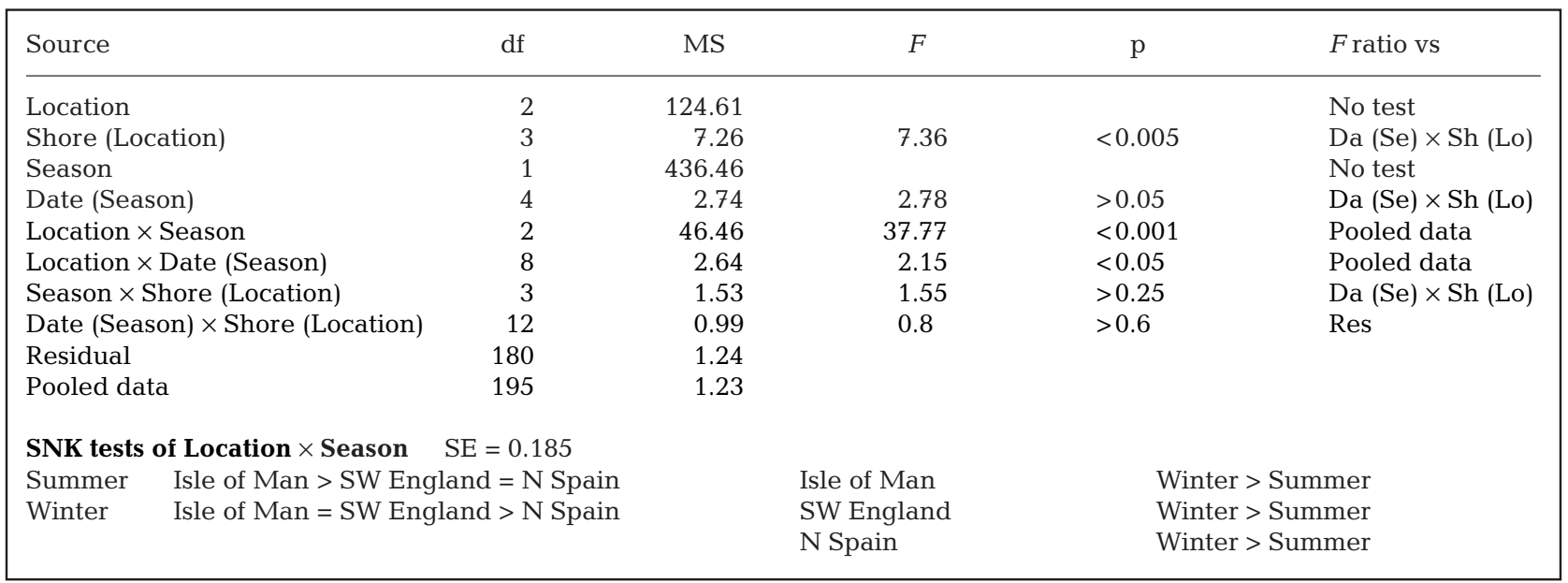

temporal scales than is possible with more conventional techniques of direct observation (e.g. Hartnoll \& Wright 1977, Little et al. 1990) or those techniques requiring sophisticated recording equipment (e.g. Della Santina et al. 1994). The main uncertainty for the wax disc method is whether the limpet alters behaviour when encountering wax discs during foraging. Our
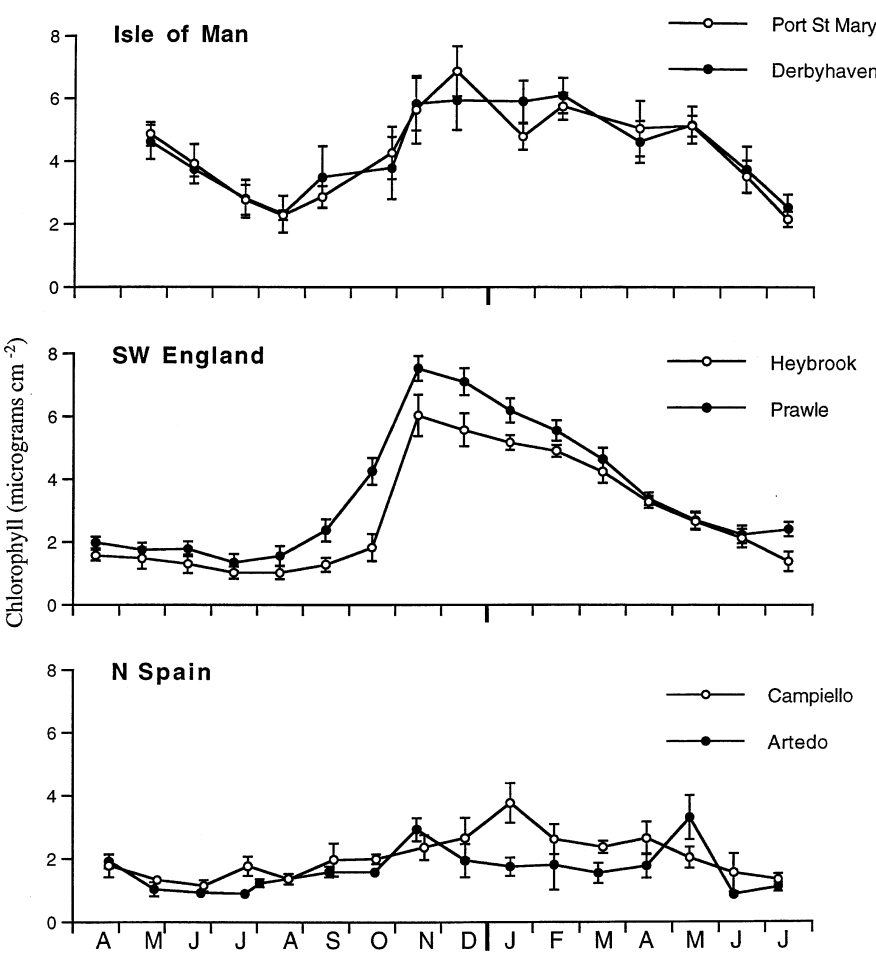

Fig. 8. Mean chlorophyll a concentrations on rock chips from 2 exposed rocky shores at each of 3 locations over 15 mo. Error bars $= \pm 1 \mathrm{SE}$ video studies confirmed that $<15 \%$ of limpets changed speed or direction on encountering a disc, suggesting only a small potential underestimate of the area of rock surface grazed.

At 3 of the 4 locations there were distinct seasonal changes in the level of grazing intensity, which were consistent between shores. Such changes could result from 2 factors: seasonal changes in the abundance of limpets, or changes in the level of foraging activity by individual limpets. The first of these is not supported by this work. There was no relationship between changes in limpet density and foraging activity. Thus, the seasonal changes in grazing intensity observed were a result of changes in the level of foraging behaviour of individual limpets.

Of the 4 locations studied, the Isle of Man, southwest England and south-west Portugal all showed a

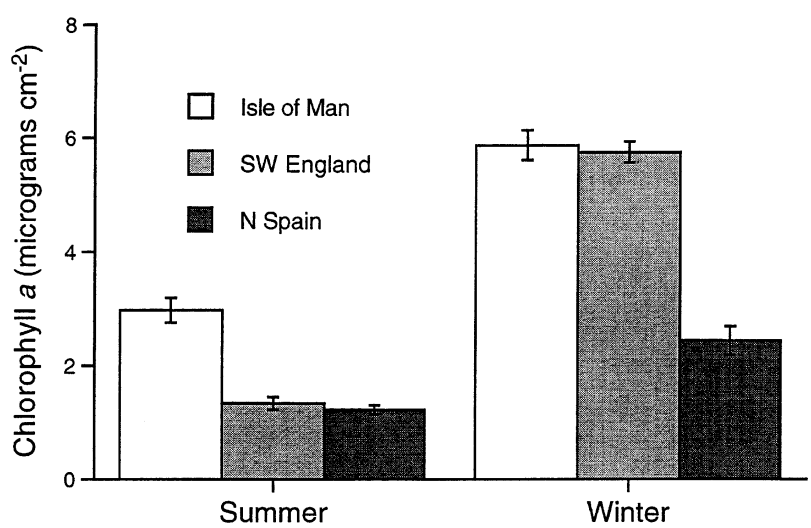

Fig. 9. Mean chlorophyll a concentrations on rock chips at 3 locations for each of 2 seasons, summer and winter. Error bars $= \pm 1 \mathrm{SE}$ 
Table 4. Pearson's correlation coefficients for comparisons between monthly measures of microalgal abundance (chlorophyll a concentration) and various physical and biological variables. Bonferroni corrected probabilities are shown for multiple tests within each location. ns: not significant; ${ }^{*} \mathrm{p}<0.05$

\begin{tabular}{|llllr|}
\hline & $\begin{array}{c}\text { Max. air } \\
\text { temperature }\end{array}$ & $\begin{array}{c}\text { Mean sea } \\
\text { temperature }\end{array}$ & $\begin{array}{c}\text { Mean } \\
\text { sunshine } \\
\text { hours }\end{array}$ & $\begin{array}{c}\text { Limpet } \\
\text { grazing } \\
\text { activity }\end{array}$ \\
\hline Isle of Man $(\mathrm{n}=14)$ & $-0.683^{*}$ & $-0.826^{*}$ & $-0.613 \mathrm{~ns}$ & $-0.173 \mathrm{~ns}$ \\
SW England $(\mathrm{n}=16)$ & $-0.826^{*}$ & $-0.558 \mathrm{~ns}$ & $-0.890^{*}$ & $-0.565 \mathrm{~ns}$ \\
N Spain (n=16) & $-0.751^{*}$ & $-0.649^{*}$ & $-0.521 \mathrm{~ns}$ & $0.510 \mathrm{~ns}$ \\
\hline
\end{tabular}

developing gonad. However, prior to our study, no experimental work has tested this hypothesis. Our observations of grazing activity and reproductive stage in $P$. vulgata on the Isle of Man, although not conclusive, do strongly suggest that large ripe gonads inhibit grazing. On both shores studied, spawning was followed by an increase in grazing activity.

Mean annual grazing level, indicated by the average monthly value of wax discs scraped, increased from $26 \%$ in the Isle of Man to $42 \%$ in south-west England and high degree of consistency in grazing activity between shores and a clear seasonal trend. In contrast, in northern Spain there was large variability between shores and no seasonal pattern. At this location, sampling of wax discs was hindered by the high frequency of marks made by crabs Pachygrapsus marmoratus and topshells Gibbula spp. This may have prevented clear results from being obtained. At the 3 locations where results were clear, grazing activity was lowest in late winter (or early spring in the case of south-west Portugal) and higher during the rest of the year. Peak grazing activity tended to occur in early summer and late autumn/early winter. A significant relationship between mean sea temperature and grazing activity was found in south-west England and the Isle of Man, but not in northern Spain. In south-west Portugal there were insufficient temperature data to determine a relationship.

Temperature has a profound effect on the physiological functions of marine organisms, and is particularly important in the intertidal zone, where the range of temperatures experienced is large. Most studies of feeding rate variation in intertidal organisms have concentrated on suspension feeders (see Newell \& Branch 1980 for review). In gastropod molluscs, radular activity has been used as an index of feeding rate, and a direct relationship between temperature and radula rasping rate been shown for Littorina littorea (Newell et al. 1971) and the patellid limpet Cellana ornata (Boyden \& Zeldis 1979). The index of grazing activity used in this study will be influenced by rasping rate, but also includes other variables such as frequency of foraging, which may not show such a direct relationship with temperature. For example the seasonal occurrence of rough seas, variability in abundance or activity of predators, extremes of air temperature at low water, and the breeding cycle may all disrupt a simple relationship between grazing activity and sea temperature. Orton et al. (1956) speculated that in the latter stages of gonad development in Patella vulgata, feeding activity is reduced or even stopped owing to the pressure exerted on surrounding tissues by the
$66 \%$ in south-west Portugal. The results for northern Spain at $23 \%$ do not fit this trend, but this is probably Differences between locations may be explained by sities increase from $29 \mathrm{~m}^{-2}$ in the Isle of Man to $141 \mathrm{~m}^{-2}$ in south-west England and $251 \mathrm{~m}^{-2}$ in south-west Portugal. Biomass (for which data are not available) as well as number is important, but the trend is clear. Another factor is the trend of annual activity. Moving southwards there is evidence to suggest that the period of late winter/early spring reduction in grazing becomes shorter and the period of high activity longer and more sustained. It would seem that towards the south there are more limpets of more species and they are feeding actively for more of the year. This observation supports the generally held but untested view of a latitudinal gradient in the balance between grazers and algae in the north-east Atlantic (Ballantine 1961, Hawkins et al. 1992); large fucoid algae which predominate in the north of Europe become increasingly restricted to sheltered shores at lower latitudes.

\section{Microalgal abundance}

In considering patterns of microalgal abundance (standing stock) in relation to grazer density and activity, it must be noted that a proper measure of food supply should ideally incorporate both standing stock and production (Underwood 1984a). Unfortunately there are serious difficulties in accurately assessing epilithic microalgal production in the field. The accumulation of chlorophyll on scraped or burnt areas (Workman 1983, Bosman \& Hockey 1988, Dye \& White 1991) or on artificial settlement surfaces (Bustamante et al. 1995) has been used as an index of microalgal production but such estimates are unduly influenced by the development of early macroalgal stages and variation in recruitment of microalgae. Given the difficulties in obtaining meaningful estimates of microalgal production, measures of standing stock were used. explained by the sampling difficulties discussed above. the large differences in density of limpets. Mean den- 
Seasonal variation in standing stock of microalgae was found at all 3 locations examined, the Isle of Man, south-west England and northern Spain. Thus, over the latitudinal gradient studied the general observation made by a number of earlier studies (Aleem 1950, Nicotri 1977, Underwood 1984a, MacLulich 1987, Fuji et al. 1991, Hill \& Hawkins 1991, Thompson 1996) of greater epilithic microalgal standing stock in winter compared to summer appears valid. We recorded consistency of pattern over both large (among locations) and small (between shores) scales.

There is a clear need for manipulative experimental studies to determine the causative factors of such seasonal variation. Examination of the relationship between physical variables and microalgal abundance can give valuable insight into where such studies should be focused. We found a significant inverse correlation of microalgal abundance with maximum monthly air temperatures at all locations, and with mean monthly sunshine hours in the south-west of England, indicating the potential importance to microalgal productivity of conditions during the period of emersion (see Aleem 1950, Castenholz 1963, Lamontagne et al. 1989). Interestingly, there was no significant relationship between limpet grazing activity and standing stock at any location. Limpet grazing is of paramount importance in controlling macroalgal colonisation of exposed mid-shore sites (see Hawkins \& Hartnoll 1983 for review), but clearly patterns of microalgal abundance are not controlled solely by limpets.

There was a general decline in microalgal abundance with decreasing latitude. Both the increase in the diversity and density of limpet grazers and the increasingly harsh summer conditions further south in Europe could be potential causative factors. Differences between locations varied with season. In the summer, the standing stock in the Isle of Man was significantly greater than in south-west England and northern Spain, which showed equivalent levels. These groupings altered in the winter when standing stock in south-west England became equivalent to the Isle of Man and higher than northern Spain. Thus, south-west England behaved similarly to the northern location in winter but to the southerly location in summer, reflecting its position on the border of 2 biogeographical zones (Lewis 1964, Southward et al. 1995). The relative abundance of organisms living within microbial films has been shown to vary among locations and seasons. For example, in the Isle of Man and southern England, diatoms were rare during the summertime but cyanobacteria were present throughout the year (Aleem 1950, Hill \& Hawkins 1991, Thompson 1996). In the tropics, cyanobacteria were the dominant microorganisms and were most abundant during the winter (Nagarkar \& Williams 1999). The chlorophyll extrac- tion methods used in this study provided a reliable index of microbial standing stock (Underwood 1984a, Fuji et al. 1991, Hill \& Hawkins 1991), but could not provide information on changes in species composition. A much more informative assessment of temporal and spatial variability in microbial communities could be obtained by direct observation using scanning electron microscopy or confocal microscopy (Norton et al. 1998). This was beyond the resources of the present broad-scale study, but should ideally be measured in parallel with standing stock during future investigations.

In summary, we have demonstrated seasonal variability in microalgal abundance over a large geographic scale, from the Isle of Man to northern Spain. There was also a clear decline in microalgal abundance with decreasing latitude. Seasonal variability in limpet grazing effort was demonstrated at 3 out of 4 locations, but no relationship between grazing effort and microalgal abundance was apparent. This study has demonstrated a high degree of generality for seasonal patterns of microalgal abundance and herbivory in microphagous gastropods on intertidal rocky shores on the Atlantic coast of Europe.

Acknowledgements. This study was supported by the Mast III Project EUROROCK MAS3-CT95-0012. R.C.T. was supported by Leverhulme Grant F/180/AO and M.F.R. by Grundy Educational Trust and the Richard Nevitt Fund. Thanks to Lisandro Benedetti-Cecchi for helpful advice on data analysis and to Luis Branco for technical assistance in Portugal. The manuscript was substantially improved by the comments of 4 referees.

\section{LITERATURE CITED}

Aleem AA (1950) Distribution and ecology of British marine littoral diatoms. J Ecol 38:75-106

Arrontes J (1993) Nature of the distributional boundary of Fucus serratus on the north shore of Spain. Mar Ecol Prog Ser 93:183-193

Ballantine WJ (1961) A biologically defined exposure scale for the comparative description of rocky shores. Field Stud 1: $1-19$

Bosman AL, Hockey PAR (1988) Life-history patterns of populations of the limpet Patella granularis: the dominant roles of food supply and mortality rate. Oecologia 75:412-419

Boyden CR, Zeldis JR (1979) Preliminary observations using an attached microphone sensor to study feeding behaviour of an intertidal limpet. Estuar Coast Mar Sci 9: 759-769

Branch GM, Branch ML (1980) Competition in Bembicium auratum (Gastropoda) and its effect on microalgal standing stock in mangrove muds. Oecologia 46:106-114

Bustamante RH, Branch GM, Eekhout S, Robertson B, Zoutendyk P, Schleyer M, Dye A, Hanekom N, Keats D, Jurd M, McQuaid C (1995) Gradients of intertidal primary productivity around the coast of South Africa and their relationships with consumer biomass. Oecologia 102:189-201 Castenholz RW (1963) An experimental study of the vertical 
distribution of littoral marine diatoms. Limnol Oceanogr 8:450-462

Creese RG, Underwood AJ (1982) Analysis of inter- and intraspecific competition amongst intertidal limpets with different methods of feeding. Oecologia 53:337-346

Della Santina P, Naylor E, Chelazzi G (1994) Long term field actography to assess the timing of foraging excursions in the limpet Patella vulgata L. J Exp Mar Biol Ecol 178: 193-203

Dye AH, White RA (1991) Intertidal microalgal production and molluscan herbivory in relation to season and elevation on two rocky shores on the east coast of Southern Africa. S Afr J Mar Sci 11:483-489

Evans RG (1947) The intertidal ecology of selected localities in the Plymouth neighbourhood. J Mar Biol Assoc UK 27: 173-218

Fuji A, Watanabe H, Ogura K, Noda T, Goshima S (1991) Abundance and productivity of microphytobenthos on a rocky shore in southern Hokkaido. Bull Fac Fish Hokkaido Univ 42:136-146

Hartnoll RG, Hawkins SJ (1985) Patchiness and fluctuations on moderately exposed shores. Ophelia 24:53-64

Hartnoll RG, Wright JR (1977) Foraging movements and homing in the limpet Patella vulgata L. Anim Behav 25:806-810

Hawkins SJ, Hartnoll RG (1983) Grazing of intertidal algae by marine invertebrates. Oceanogr Mar Biol Annu Rev 21: 195-282

Hawkins SJ, Hartnoll RG, Kain JM, Norton TA (1992) Plantanimal interactions on hard substrata in the North-east Atlantic. In: John DM, Hawkins SJ, Price JH (eds) Plantanimal interactions in the marine benthos. Clarendon Press, Oxford, p 1-32

Hill AS, Hawkins SJ (1990) An investigation of methods for sampling microbial films on rocky shores. J Mar Biol Assoc UK 70:77-88

Hill AS, Hawkins SJ (1991) Seasonal and spatial variation of epilithic microalgae distribution and abundance and its ingestion by Patella vulgata on a moderately exposed rocky shore. J Mar Biol Assoc UK 71:403-423

Lamontagne I, Cardinal A, Fortier L (1989) Environmental forcing versus endogenous control of photosynthesis in intertidal epilithic microalgae. Mar Ecol Prog Ser 51:177-187

Lewis JR (1964) The ecology of rocky shores. English Universities Press, London

Little C, Morritt D, Paterson DM, Stirling P, Williams GA (1990) Preliminary observations on factors affecting foraging activity in the limpet Patella vulgata. J Mar Biol Assoc UK 70:181-195

Lock MA (1993) Attached microbial communities in rivers. In: Ford TA (ed) Aquatic microbiology. Blackwells, Oxford, p 113-138

MacLulich JH (1986) Experimental evaluation of methods for sampling and assaying intertidal epilithic microalgae. Mar Ecol Prog Ser 34:275-280

MacLulich JH (1987) Variations in the density and variety of intertidal epilithic microflora. Mar Ecol Prog Ser 40: 285-293

Morrisey DJ, Underwood AJ, Howitt L, Stark JS (1992) Temporal variation in soft-sediment benthos. J Exp Mar Biol Ecol 164:233-245

Nagarkar S, Williams GA (1997) Comparative techniques to quantify cyanobacteria dominated epilithic biofilms on tropical rocky shores. Mar Ecol Prog Ser 154:281-291
Nagarkar S, Williams GA (1999) Spatial and temporal variation of cyanobacteria-dominated epilithic communities on a tropical shore in Hong Kong. Phycologia 38:385-393

Newell RC, Branch GM (1980) The influence of temperature on the maintenance of metabolic energy balance in marine invertebrates. Adv Mar Biol 17:329-396

Newell R, Pye P, Ahsanullah M (1971) Factors affecting the feeding rate of the winkle Littorina littorea. Mar Biol 9: 138-144

Nicotri ME (1977) Grazing effects of four marine intertidal herbivores on the microflora. Ecology 58:1020-1032

Norton T, Thompson R, Pope J, Veltkamp C, Banks B, Howard C, Hawkins S (1998) Using confocal laser scanning microscopy, scanning electron microscopy and phase contrast light microscopy to examine marine biofilms. Aquat Microb Ecol 16:199-204

Orton JH, Southward AJ, Dodd JM (1956) Studies on the biology of limpets. II. The breeding of Patella vulgata L. in Britain. J Mar Biol Assoc UK 35:149-176

Potts M (1980) Blue green algae (Cyanophyta) in marine coastal environments of the Sinai Peninsula; distribution, zonation, stratification and taxonomic diversity. Phycologia 19:60-73

Raffaelli D, Hawkins SJ (1996) Intertidal ecology. Chapman and Hall, London

Southward AJ, Hawkins SJ, Burrows MT (1995) Seventy years' observations of changes in distribution and abundance of zooplankton and intertidal organisms in the western English Channel in relation to rising sea temperature. J Therm Biol 20:1-2

Thompson RC (1996) The ecology of epilithic microalgae on Manx shores. PhD thesis, University of Liverpool, Port Erin

Thompson RC, Johnson LE, Hawkins SJ (1997) A method for spatial and temporal assessment of gastropod grazing intensity in the field: the use of radula scrapes on wax sufaces. J Exp Mar Biol Ecol 218:63-76

Thompson RC, Tobin M, Hawkins S, Norton T (1999) Problems in extraction and spectrophotometric determination of chlorophyll from epilithic microbial biofilms: towards a standard method. J Mar Biol Assoc UK 79:551-558

Underwood AJ (1984a) The vertical distribution and seasonal abundance of intertidal microalgae on a rocky shore in New South Wales. J Exp Mar Biol Ecol 78:199-220

Underwood AJ (1984b) Vertical and seasonal patterns in competition for microalgae between intertidal gastropods. Oecologia 64:211-222

Underwood AJ (1997) Experiments in ecology. Their logical design and interpretation using analysis of variance. Cambridge University Press, Cambridge

Wahl M (1989) Marine epibiosis. I. Fouling and antifouling: some basic aspects. Mar Ecol Prog Ser 58:175-189

Whitton BA, Potts M (1982) Marine littorals. In: Carr NG, Whitton BA (eds) The biology of cyanobacteria. Blackwell, Oxford, p 515-542

Williams GA (1994) The relationship between shade and molluscan grazing in structuring communities on a moderately-exposed tropical rocky shore. J Exp Mar Biol Ecol 178:79-95

Winer BJ (1971) Statistical principles in experimental design. McGraw-Hill, Tokyo

Workman C (1983) Comparisons of energy partitioning in contrasting age-structured populations of the limpet Patella vulgata (L). J Exp Mar Biol Ecol 68:81-103

Submitted: December 16, 1999; Accepted: August 8, 2000 Proofs received from author(s): February 1, 2001 